\title{
INTRASPECIFIC MOLECULAR PHYLOGENY IN THE YELLOW WARBLER (DENDROICA PETECHIA), AND IMPLICATIONS FOR AVIAN BIOGEOGRAPHY IN THE WEST INDIES
}

\author{
Nedra K. KLeIN'AND Wesley M. Brown \\ Museum of Zoology and Department of Biology, University of Michigan, \\ Ann Arbor, Michigan 48109 \\ E-mail: Wesley.Brown@um.cc.umich.edu
}

\begin{abstract}
A phylogenetic analysis of mitochondrial DNA (mtDNA) restriction sites was used to examine the evolutionary history of populations of yellow warbler (Dendroica petechia) sampled from North America, Central America, South America, and the West Indies. Thirty-seven haplotypes were identified, and only one was found in more than one of these regions. Estimated sequence divergence among haplotypes ranged from 0.14 to $3.17 \%$, and mtDNAs from North American migratory populations clearly were differentiated from those of most tropical sedentary populations. Parsimony analysis of haplotypes suggested multiple colonizations of the West Indies archipelago and of individual Caribbean islands. The inference of multiple colonizations has important implications for studies of avian ecology and evolution in this region.
\end{abstract}

Key words. - Bird, Caribbean region, Dendroica petechia, island biogeography, mtDNA, phylogeny, West Indies.

Received September 28, 1992. Accepted March 18, 1994.

Studies of island biogeography have contributed greatly to our understanding of ecological and evolutionary processes (MacArthur and Wilson 1963, 1967; Lack 1976; Berry 1983; Williams 1989). Such inferences about process can become even more powerful, however, when they are made within an historical framework provided by estimates of phylogenetic relationship among island populations and species (Rosen 1975; Eldredge and Cracraft 1980; Wiley 1981; Guyer and Savage 1986; Kluge 1988; Miller and Miller 1989).

Caribbean islands have acquired their fauna either from overwater dispersal (Darlington 1938; Bond 1963, 1978; Pregill 1981; Koopman 1989), or as relicts through fragmentation of a formerly widespread distribution (Rosen 1975; Kluge 1988). Vicariance explanations of distribution and evolutionary diversification have been proposed for several faunal groups on Caribbean islands (Rosen 1975; Kluge 1988; Miller and Miller 1989). However, many avian species are too recent in origin (Brodkorb 1971; Feduccia and Martin 1976; Feduccia 1977; Olson 1985) for the vicariance explanations proposed for oth-

\footnotetext{
1 Present address: Department of Ornithology, American Museum of Natural History, Central Park West at 79th, New York, NY 10024-5192, E-mail: nklein@AMNH.org.
}

er taxa, and most likely have arrived at their present distributions via dispersal from surrounding continental areas and from other islands (Bond 1963, 1978; Seutin et al. 1993).

Nevertheless, testable predictions of sources of colonists can be made based on distances to the nearest land masses. In a series of papers on West Indian birds, Bond (1948, 1961, 1963, 1978, 1979, 1993) documented distributions and discussed taxonomic relationships of West Indian birds. Basing his hypotheses on current faunal distributions, phenotypic similarities, and inferred affinities to mainland groups, he proposed two main sources of the Caribbean avifauna: northern South America for many of the Lesser Antillean species, and Central and North America for Greater Antillean and some Lesser Antillean species. He proposed multiple colonizations from these sources for island populations of widespread species.

Whether single or multiple colonizations have occurred in the West Indies is an important distinction for inferences about evolution within this region. The implication of a widespread species having colonized the archipelago multiple times from different sources is that island populations would not constitute a monophyletic group and would thus not be each others' closest relatives. Monophyly of island populations is an implicit assumption of many evolutionary and ecological studies of species on archipelagoes 
(MacArthur and Wilson 1967; Ricklefs and Cox 1972, 1978).

Another assumption of many island biogeographic studies of colonizing species is that populations on adjacent islands are each others' closest relatives; that is, their distributions are the result of a stepping-stone process of colonization (Darlington 1938; MacArthur and Wilson 1967; Ricklefs and Cox 1972, 1978). An alternative is a colonization pattern that is random with respect to geography. Under the stepping-stone model, islands arranged linearly (e.g., the Lesser Antilles) are colonized sequentially, beginning with that closest to the mainland source (Williams 1989). Individual island populations would be derived from those on other islands or the adjacent mainland, and heritable differences among them should thus be due to selection or random differentiation processes rather than to different phylogenetic histories. If, however, a widespread species has colonized the archipelago multiple times from different source populations, there may be areas where populations on adjacent islands are descendants of different ancestral colonizers. Differences among such populations may thus be due to their different genealogies.

A phylogenetic inference of relationships among island and mainland populations of a widespread taxon is useful both because it allows testing the models of single and multiple colonizations of archipelagoes (different patterns of relationship are predicted under each) and because potential interpretive problems associated with missing taxa (islands that were never colonized or whose populations have been extirpated) can be eliminated. Under the model of a single colonization of an archipelago, monophyly of island populations is predicted. Polyphyly is predicted under the multiple-colonization model, provided founders came from different source populations. It is difficult to test models of island colonization pattern within archipelagoes, however, because (1) any tree topology is consistent with a random colonization model (i.e., the random model is not falsifiable), and (2) although a pectinate tree is predicted under the steppingstone model, if colonization has occurred rapidly, or if there has been any postcolonization movement among islands, the comblike pattern of historical relationship will not be recoverable. Nevertheless, one can test the prediction of the stepping-stone model that populations on adjacent islands should be each others' closest relatives.
We present here an estimate of the phylogenetic relationships among populations of yellow warbler (Dendroica petechia), a widespread, polytypic avian species. The phylogenetic reconstruction is based on a restriction endonuclease analysis of mitochondrial DNA (mtDNA). We use the mtDNA phylogeny to examine the evolutionary history of resident populations in the West Indies and tropical continental areas. We test the hypothesis that the West Indies has been colonized multiple times by different source populations of yellow warbler, as suggested by Bond $(1963,1978)$ for widespread Caribbean birds. If multiple colonizations have occurred, the Caribbean samples should not form a monophyletic group relative to other samples. The analysis also is used to infer colonization sources, as has been done for other groups of island organisms (Ashley and Wills 1987; Phillips et al. 1989), and to test the critical prediction of the stepping-stone colonization model that populations on adjacent islands are closely related to each other.

\section{METHODS}

Specimens were collected by shotgun or mist net from 1986-1990. A total of 194 yellow warblers was used in this study. General localities and sample sizes were: Michigan (17), North Carolina (9), Washington (6), Baja California (1), Florida Keys (1), Jamaica (9), Dominican Republic (10), Puerto Rico (17), U.S. Virgin Islands (24), Montserrat (8), Guadeloupe (5), Dominica (6), Martinique (4), St. Lucia (4), Venezuela (40), Panama (13), Costa Rica (20). Populations from Michigan, North Carolina, and Washington are wholly migratory. The rest are wholly sedentary tropical residents.

Although a few estimates of historical relationships among paruline warblers exist (Mengel 1964; Barrowclough and Corbin 1978; Raikow 1978; Bledsoe 1988; Sibley and Ahlquist 1990), none of the studies include Dendroica petechia. Preliminary allozyme evidence (Avise et al. 1980) suggests that the yellow warbler may fall outside of a group consisting of other Dendroica. In the absence of an explicit hypothesis of relationship among $D$. petechia and other warblers, choice of outgroup taxa was done with the goal of encompassing a wide range of inferred divergence levels relative to the ingroup (Maddison et al. 1984). Outgroup species (with sample sizes and localities) were: $D$. pensylvanica (2, Michigan), $D$. discolor (2, Florida), Setophaga ruticilla (1, Michigan), Parula americana (1, North Carolina), 
Geothlypis trichas (2, Michigan), and Basileuterus culicivorus (1, Venezuela). All outgroups except $B$. culicivorus are migratory North American species. Basileuterus is a wholly sedentary, Neotropical genus that is the probable sister taxon to the genera of largely migratory North American warblers (Raikow 1978; Sibley and Ahlquist 1990).

Within 5 to $15 \mathrm{~min}$ after death, whole birds were frozen on dry ice or tissues were removed and frozen in liquid nitrogen. Tissues removed in the field were stored in liquid nitrogen until they were transported back to the Laboratory of Molecular Systematics at the University of Michigan Museum of Zoology, where they were stored at $-70^{\circ} \mathrm{C}$ until processing. Birds originally frozen whole on dry ice were also stored at $-70^{\circ} \mathrm{C}$ until laboratory analysis, when the tissues were removed and processed before thawing.

Voucher specimens (museum study skins, skeletons, or skins and partial skeletons) were prepared for most individuals from which mtDNA was purified. These specimens are deposited in collections at the University of Michigan Museum of Zoology, Ann Arbor; American Museum of Natural History, New York; Florida State University, Tallahassee; North Carolina State Natural History Museum, Raleigh; Burke Museum, Seattle; National Museum of Natural History, Washington, D.C.; Museo Nacional de Costa Rica, San Jose; Museo de Historia Natural Fundación La Salle, Caracas, Venezuela; Museo de Zoología Facultad de Ciencias, Universidad Autónoma de México, Mexico City; and the Department of Natural Resources, San Juan, Puerto Rico.

All birds used in the analysis were local residents as inferred from the presence of nests, territorial behavior, or relative development of gonads.

Isolation, purification, and restriction endonuclease digestion of mitochondrial DNA followed methods outlined in Lansman et al. (1981) and Dowling et al. (1990). Purified mtDNA was isolated from liver, heart, or pectoral muscle. The amount of tissue used ranged from $0.03 \mathrm{~g}$ to $0.3 \mathrm{~g}$, and the homogenization buffer consisted of one part $0.5 \mathrm{M}$ sucrose in TE to five parts 200 mM EDTA, $10 \mathrm{mM} \mathrm{NaCl}, 10 \mathrm{mM}$ Tris.

Restriction enzymes producing variable fragment patterns among three samples (from Michigan, Costa Rica, and Puerto Rico) were used to digest the remaining mtDNAs. For each enzyme, 15 samples ( 1 from each of 15 localities encom- passing the geographic range of samples) digested with that enzyme were run together on one set of agarose and polyacrylamide gels to facilitate comparison of fragment sizes among different haplotypes. Other gel sets consisted of the remaining individuals. DNA was digested to completion (2-14 h) with an excess of the following enzymes: $A v a \mathrm{I}, A v a \mathrm{II}, B a m H \mathrm{I}, B c I \mathrm{I}, B g l \mathrm{II}, B s t E \mathrm{II}$, ClaI, HindIII, KpnI, NdeI, NheI, PvuII, and SpeI. Digestions were performed under conditions recommended by the suppliers (Boehringer-Mannheim, New England Biolabs, and Toyobo). Fragments were end-labeled with $\mathrm{P}^{32}$ (Brown 1980; Wright et al. 1983; Dowling et al. 1990), run in $1 \times$ TBE buffer on both agarose $(0.8-1.2 \%)$ and polyacrylamide $(3.5-5 \%)$ vertical gels, and visualized by autoradiography (Brown 1980). A size standard of lambda phage DNA digested with HindIII mixed with $\phi \times 174$ phage DNA digested with HaeIII was included on each gel. Fragment sizes were estimated from calibration curves plotted from $\log _{10}$ fragment size versus distance migrated of size-standard fragments. Mean size estimates of the mtDNA molecule for each species were calculated from the sizes estimated from fragments generated by each enzyme for the mapped individuals.

Because of potential errors in assuming homology of cleavage sites that produce fragments of similar size, direct mapping of relative positions of cleavage sites is recommended for phylogenetic analyses (Templeton 1983b; Moritz et al. 1987; Dowling et al. 1990; Swofford and Olsen 1990). Even in closely related organisms, mtDNA fragments of similar size can be produced by cleavage at nonhomologous sites (Pumo et al. 1988; Klein pers. obs.). Cleavage sites for each outgroup species and for two yellow warbler mtDNA lineages (WI-A from the Dominican Republic and NA-E from Michigan; estimated sequence divergence of $2.3 \%$ ) were therefore mapped independently, using double and triple digests (Brown and Vinograd 1974; Dowling et al. 1990) (table 1). Cleavage-site losses relative to the mapped sites and site homology were inferred from fragment pattern comparisons with those for mapped haplotypes (Vawter and Brown 1986; Dowling and Brown 1989). The positions of cleavage sites that were gained relative to the mapped haplotypes were determined with additional double digests. Additional double-digests were also used to verify positions in unmapped individuals of synapomorphic restriction sites that uniquely identified clades. 
TABLE 1. Restriction-site map positions (in $\mathrm{kb}$, to nearest $0.05 \mathrm{~kb}$ ) relative to $\mathrm{ClaI} \mathrm{A}$, and presence/absence (1/0) of site. ?, presence/absence of site not determined. Outgroup species are OG-A, Dendroica pensylvanica; OG-B, Dendroica discolor; OG-C, Parula americana; OG-D, Geothlypis trichas; OG-E, Setophaga ruticilla; OGF, Basileuterus culicivorus. Enzyme abbreviatons as follows: AI: $A v a \mathrm{I}, \mathrm{AII}: A v a \mathrm{II}, \mathrm{Ba}: B a m \mathrm{HI}, \mathrm{Bc}: B c I \mathrm{I}, \mathrm{B}: B g I \mathrm{II}$, Bs: BstEII, C: ClaI, H: HindIII, K: KpnI, Nd: NdeI, N: NheI, P: PvuII, Sa: SacII, S: SpeI.

\begin{tabular}{|c|c|c|c|c|c|c|}
\hline \multirow[b]{3}{*}{ Position } & \multirow[b]{3}{*}{ Site } & \multicolumn{5}{|c|}{ Haplotypes } \\
\hline & & $\begin{array}{l}\text { West Indies } \\
\text { WI- }\end{array}$ & $\begin{array}{c}\text { Central America } \\
\text { CA- }\end{array}$ & $\begin{array}{l}\text { Venezuela } \\
\text { VE- }\end{array}$ & $\begin{array}{l}\text { North America } \\
\text { NA- }\end{array}$ & $\begin{array}{l}\text { Outgroups } \\
\text { OG- }\end{array}$ \\
\hline & & ACEFGBHIJK & ABCDEFGHIJ & $A F B C D E$ & ACDEFGIJLMN & $A B C D E F$ \\
\hline$-0-$ & $\mathrm{C}$ & 1111111111 & 1111111111 & 111111 & 11111111111 & 111111 \\
\hline $0.1^{*}$ & Nd & 0000000000 & 0000000000 & 000000 & 00000000001 & 000000 \\
\hline 0.6 & $\mathrm{~S}$ & 0000000000 & 0000000000 & 000000 & 00000000000 & 000100 \\
\hline 0.75 & $\mathbf{H}$ & 1111001111 & 0000010100 & 001111 & 00000000000 & 000000 \\
\hline 1.1 & $\mathbf{H}$ & 1111111111 & 1111111111 & 111111 & 11111111111 & 111111 \\
\hline 1.2 & AII & 1111111111 & 1111111111 & 111111 & 11111110111 & 111111 \\
\hline 1.2 & $\mathbf{H}$ & 0000000000 & 0000000000 & 000000 & 00000000000 & 000010 \\
\hline 1.4 & Sa† & $1 ? ? ? 1 ? ? ? 1 ?$ & ?????????? & ?????? & ???1??????? & 111111 \\
\hline 1.5 & $\mathbf{S}$ & 1111111111 & 1111111111 & 111111 & 11111111111 & 111111 \\
\hline 1.7 & AII & 1111111111 & 1111111111 & 111111 & 00000000000 & 001000 \\
\hline 1.8 & $\mathrm{BC}$ & 1111111111 & 1111111111 & 111111 & 11111111111 & 110101 \\
\hline 1.85 & AII & 1111111111 & 1111111111 & 111111 & 11111111111 & 111111 \\
\hline 2.05 & $\mathbf{N}$ & 1111111111 & 1111111111 & 111111 & 11111111111 & 111111 \\
\hline 2.25 & AII & 0000000000 & 0000000000 & 000000 & 00000000000 & 000101 \\
\hline 2.3 & $\mathbf{S}$ & 1111111111 & 1111111111 & 111111 & 11111111111 & 110111 \\
\hline 2.4 & $\mathrm{~N}$ & 1111111111 & 1111111111 & 111111 & 11111111111 & 111110 \\
\hline 2.5 & $\mathrm{Bc}$ & 0000000000 & 0000000000 & 010000 & 00000000000 & 001000 \\
\hline 2.55 & $\mathbf{H}$ & 0000000000 & 0000000000 & 000000 & 00000000000 & 010000 \\
\hline 2.6 & AII & 0000000000 & 0000000000 & 000000 & 00000000000 & 000011 \\
\hline $2.75 \S$ & AII & 0000000000 & 0000000000 & 000000 & 00000000000 & 000001 \\
\hline 2.85 & $\mathbf{S}$ & 0000000010 & 0000000000 & 000000 & 00000000000 & 000100 \\
\hline 3.0 & $\mathbf{H}$ & 0000000000 & 0000000000 & 000000 & 00000000000 & 111111 \\
\hline 3.0 & AI & 1111111111 & 1111111111 & 111111 & 11111111111 & 000000 \\
\hline 3.1 & Bs & 0000000000 & 0000000000 & 000000 & 00000000000 & 000100 \\
\hline 3.6 & $\mathrm{~K}$ & 0000000000 & 0000000000 & 000000 & 00000000000 & 010001 \\
\hline 3.6 & $\mathrm{P}$ & 1111111111 & 1111111111 & 111111 & 11111111111 & 110111 \\
\hline $4.3 \S$ & AII & 0000000000 & 0000000000 & 000000 & 00000000000 & 000101 \\
\hline 4.4 & Nd & 0000000000 & 0000000000 & 000000 & 00000000101 & 010000 \\
\hline 4.6 & AII & 1111111111 & 1111111111 & 111111 & 11111111111 & 111111 \\
\hline 4.7 & $\mathrm{C}$ & 0000000000 & 0000000000 & 000000 & 00000000000 & 001000 \\
\hline 4.9 & AII & 1111110001 & 1111111111 & 111111 & 11111111111 & 101111 \\
\hline 4.9 & $\mathbf{K}$ & 1111101111 & 1111111111 & 111111 & 11111111111 & 111111 \\
\hline 5.05 & AII & 0000000000 & 0000000000 & 000000 & 00000000000 & 001000 \\
\hline 5.1 & $\mathbf{S}$ & 1111111111 & 1111111111 & 111111 & 11111111111 & 110110 \\
\hline 5.2 & $\mathrm{H}$ & 1111111111 & 1111111111 & 111111 & 11111111110 & 011111 \\
\hline 5.3 & AI & 0000110000 & 0000000000 & 110100 & 00000000000 & 110000 \\
\hline 5.5 & Bs & 1111111111 & 0011110101 & 111111 & 11111111111 & 100011 \\
\hline 5.5 & $\mathrm{Bc}$ & 1111111111 & 1111111111 & 111111 & 11111111111 & 111100 \\
\hline 5.7 & AI & 1111111111 & 1111111111 & 111111 & 11111111111 & 111111 \\
\hline 5.8 & Bs & 1111111111 & 1111111111 & 110100 & 11111111111 & 100000 \\
\hline 5.8 & $\mathbf{P}$ & 1111111111 & 1111111111 & 111111 & 11111111111 & 111111 \\
\hline 5.9 & $\mathbf{P}$ & 0000000000 & 0000000000 & 000000 & 00000000000 & 000001 \\
\hline 6.2 & $\mathbf{P}$ & 0000110010 & 0000000000 & 110100 & 11111111111 & 111100 \\
\hline 6.25 & $\mathbf{S}$ & 1111111111 & 1111111111 & 111111 & 11111111111 & 101101 \\
\hline 6.5 & $\mathrm{Nd}$ & 1111111111 & 1111111111 & 111101 & 11111111111 & 111101 \\
\hline 6.5 & B & 0001000000 & 0000000000 & 000000 & 00000000000 & 000000 \\
\hline 6.8 & $\overline{\mathbf{S}}$ & 0000000000 & 0000000000 & 000000 & 00000000000 & 001000 \\
\hline 7.0 & Bs & 1111001111 & 0000010100 & 001011 & 00000000000 & 000000 \\
\hline 7.0 & $\mathrm{AI}$ & 0000000000 & 0000000000 & 000000 & 00000000000 & 010000 \\
\hline 7.1 & B & 1111111111 & 1111111111 & 111111 & 11111111111 & 010000 \\
\hline 7.2 & $\bar{S}$ & 0000110000 & 0000000000 & 110000 & 00000000000 & 000000 \\
\hline 7.3 & B & 0000111111 & 1111111111 & 111111 & 11111111111 & 110000 \\
\hline 7.4 & AII & 0000000000 & 0000000000 & 000000 & 00000000000 & 000100 \\
\hline 7.4 & $\mathbf{H}$ & 0000000000 & 0000000000 & 000000 & 00000000000 & 000001 \\
\hline
\end{tabular}


TABle 1. Continued.

\begin{tabular}{|c|c|c|c|c|c|c|}
\hline & & $\begin{array}{l}\text { West Indies } \\
\text { WI- }\end{array}$ & $\begin{array}{c}\text { Central America } \\
\text { CA- }\end{array}$ & $\begin{array}{l}\text { Venezuela } \\
\text { VE- }\end{array}$ & $\begin{array}{c}\text { North America } \\
\text { NA- }\end{array}$ & $\begin{array}{l}\text { Outgroups } \\
\text { OG- }\end{array}$ \\
\hline Position & Site & ACEFGBHIJK & ABCDEFGHIJ & AFBCDE & ACDEFGTJLMN & ABCDEF \\
\hline 7.5 & $\mathbf{H}$ & 1101111111 & 1111111111 & 111111 & 10111111111 & 111111 \\
\hline 7.6 & $\mathrm{Bc}$ & 1111000000 & 0000000000 & 000000 & 00000000000 & 000000 \\
\hline 7.8 & $\mathbf{N}$ & 0000000000 & 0000000000 & 000000 & 00000000000 & 000100 \\
\hline 7.9 & $\mathbf{K}$ & 0000000000 & 0000000000 & 000000 & 00000000000 & 000001 \\
\hline 8.1 & $\mathrm{H}$ & 1111111111 & 1111111111 & 111111 & 11111111111 & 111110 \\
\hline 8.5 & AI & 1111111110 & 0011011100 & 111111 & 11111111111 & 000100 \\
\hline 8.6 & Bs & 0000000000 & 0000000000 & 000000 & 00000000000 & 011000 \\
\hline 8.6 & AI & 0000110000 & 0000000000 & 110100 & 00000000000 & 000000 \\
\hline 8.9 & $\mathbf{S}$ & 1111111111 & 1111111111 & 111111 & 11111111111 & 111111 \\
\hline 9.1 & $\mathbf{H}$ & 0000000000 & 0000000000 & 000000 & 00000000000 & 001010 \\
\hline 9.3 & $\mathrm{Ba}$ & 1111111111 & 1111111111 & 111111 & 11111111111 & 110000 \\
\hline 9.4 & $\mathbf{H}$ & 1111111111 & 1011111111 & 111111 & 11111111111 & 111011 \\
\hline 9.45 & $\mathbf{S}$ & 0000000000 & 0000000000 & 000000 & 00000000000 & 000001 \\
\hline 9.6 & $\mathrm{Nd}$ & 0000000000 & 0000000000 & 000000 & 11111111111 & 011111 \\
\hline 9.7 & AII & 1111111111 & 1111111111 & 111111 & 11111111111 & 100001 \\
\hline 9.8 & $\mathbf{S}$ & 1111111111 & 1111111111 & 111111 & 11111111111 & 101001 \\
\hline 9.8 & $\mathrm{Ba}$ & 1111111111 & 1111111111 & 111111 & 11111111111 & 111010 \\
\hline 10.0 & $\mathrm{C}$ & 0000000000 & 0000000000 & 000000 & 00000000000 & 000001 \\
\hline 10.3 & $\mathrm{Bc}$ & 0000000000 & 0000000000 & 000000 & 00000000000 & 000001 \\
\hline 10.4 & Bs & 0000000000 & 0000000000 & 000000 & 00000000000 & 100101 \\
\hline 10.5 & $\mathrm{~N}$ & 0000000000 & 0000000000 & 000000 & 00000000000 & 001000 \\
\hline 10.5 & $\mathbf{B a}$ & 1111111111 & 1111111111 & 111111 & 11111111111 & 111111 \\
\hline 10.6 & $\mathrm{Bc}$ & 1111111111 & 1111111111 & 111111 & 11111111111 & 111011 \\
\hline 10.7 & $\mathbf{S}$ & 0000000000 & 0000000000 & 000000 & 00000000000 & 010110 \\
\hline 10.8 & $\mathbf{N}$ & 1111111111 & 1111111111 & 111111 & 11111111111 & 010000 \\
\hline 11.0 & AII & 0000000000 & 0000000000 & 000000 & 00000000000 & 001000 \\
\hline $11.1 \ddagger$ & $\mathrm{Ba}$ & 0000000110 & 0000000000 & 000000 & 00000000000 & 000000 \\
\hline 11.1 & $\mathrm{~K}$ & 1111111111 & 1111111111 & 111111 & 00000000000 & 000000 \\
\hline 11.4 & AII & 1111111111 & 1111111111 & 110101 & l1111111111 & 111111 \\
\hline 11.5 & $\mathrm{AI}$ & 0000000000 & 0000000000 & 000000 & 00000000000 & 000100 \\
\hline 11.7 & AII & 1111001111 & 0000010100 & 001011 & 00000000000 & 000000 \\
\hline 11.9 & $\mathbf{P}$ & 1111111111 & 1111111111 & 111111 & 11111111111 & 011110 \\
\hline 12.1 & $\mathbf{P}$ & 1111111111 & 1111111111 & 111111 & 00000111111 & 010010 \\
\hline 12.15 & AII & 1111111111 & 1111111111 & 111111 & 11111111111 & 101010 \\
\hline 12.5 & $\mathbf{H}$ & 0000000000 & 0000000000 & 000000 & 00000000000 & 000110 \\
\hline 12.7 & $\mathbf{S}$ & 1111111111 & 1111111111 & 111111 & 11111111111 & 111101 \\
\hline 12.7 & AII & 0000000000 & 0000000000 & 000000 & 00000000000 & 000010 \\
\hline 12.8 & $\mathbf{N}$ & 0000000000 & 0000000000 & 000000 & 00000000000 & 000010 \\
\hline 12.8 & Bs & 1111111111 & 1111111111 & 111111 & 00000111111 & 110010 \\
\hline 13.0 & $\mathbf{H}$ & 0000000000 & 0000000000 & 000000 & 00000000000 & 000010 \\
\hline 13.1 & $\mathbf{N}$ & 0000000000 & 0000000000 & 000000 & 00100000000 & 000000 \\
\hline 13.4 & $\mathbf{B a}$ & 1111111111 & 1111111111 & 111111 & 11111111111 & 111101 \\
\hline 13.5 & $\mathrm{Nd}$ & 1111111111 & 1111111111 & 111111 & 11111111111 & 111111 \\
\hline 13.75 & $S$ & 1111111111 & 1111111011 & 111111 & 11111101010 & 101110 \\
\hline 13.8 & Nd & 1111111111 & 0001100001 & 110100 & 11111011000 & 000000 \\
\hline 14.1 & $\mathbf{S}$ & 0000000000 & 0000000000 & 000000 & 00000000000 & 000100 \\
\hline 14.1 & Nd & 0000000000 & 0000000000 & 000000 & 00000100000 & 000000 \\
\hline 14.2 & $\mathbf{N}$ & 1111111111 & 1111111111 & 111111 & 00000000000 & 110010 \\
\hline 14.3 & Bs & 0000000000 & 0000000000 & 000000 & 00000000000 & 000111 \\
\hline 14.4 & $\mathbf{P}$ & 0000000000 & 0000000000 & 000000 & 00000000000 & 010000 \\
\hline 14.5 & AI & 1111111111 & 1111111111 & 111111 & 11111111111 & 111111 \\
\hline 14.9 & $\mathrm{Ba}$ & 1111111001 & l111111111 & 001111 & 00001000000 & 111101 \\
\hline 14.9 & AII & 0000000110 & 0000000000 & 110000 & 11110111111 & 000001 \\
\hline 15.2 & B & 1111111111 & 1111111111 & 111111 & 11111111111 & 111111 \\
\hline 15.35 & $\mathrm{H}$ & 0000000000 & 0000000000 & 000000 & 00000000000 & 000101 \\
\hline 15.4 & AII & 0000000000 & 0000000000 & 000000 & 00000000000 & 000011 \\
\hline 15.45 & $\mathbf{K}$ & 1111111111 & 1111111111 & 111111 & 11111111111 & 111111 \\
\hline 15.6 & AII & 0000000000 & 0000000000 & 000000 & 00000000000 & 000001 \\
\hline 15.8 & AII & 0100000000 & 0000000000 & 000000 & 00000000000 & 000000 \\
\hline
\end{tabular}


TABle 1. Continued.

\begin{tabular}{|c|c|c|c|c|c|c|}
\hline & & $\begin{array}{l}\text { West Indies } \\
\text { WI- }\end{array}$ & $\begin{array}{c}\text { Central America } \\
\text { CA- }\end{array}$ & $\begin{array}{c}\text { Venezuela } \\
\text { VE- }\end{array}$ & $\begin{array}{c}\text { North America } \\
\text { NA- }\end{array}$ & $\begin{array}{c}\text { Outgroups } \\
\text { OG- }\end{array}$ \\
\hline Position & Site & ACEFGBHIJK & ABCDEFGHIJ & $A F B C D E$ & ACDEFGIJLMN & $A B C D E F$ \\
\hline 16.0 & Nd & 1111111111 & 1111111111 & 111111 & 11111111111 & 111111 \\
\hline 16.5 & AI & 1111111111 & 1111111111 & 111111 & 11111111111 & 111111 \\
\hline 16.8 & Saf & 1???1???1? & ?????????? & ?????? & ???1??????? & 111111 \\
\hline 16.8 & $\mathbf{P}$ & 0000000000 & 0000000000 & 000000 & 11101111111 & 000000 \\
\hline 17.0 & AII & 1111111111 & 1111111111 & 111111 & lill1111111 & 111111 \\
\hline 17.0 & $\mathrm{AI}$ & 0000000000 & 0000000000 & 000000 & 00000000000 & 000100 \\
\hline 17.1 & AII & 0000000000 & 0000100010 & 000000 & 00000000000 & 000000 \\
\hline 17.1 & $\mathrm{C}$ & & & & & \\
\hline
\end{tabular}

* Other possible location is at $3.2 \mathrm{~kb}$.

$\dagger$ Most individuals were not screened for Sacll because these two sites are conserved in vertebrates. SacII sites not included in phylogenetic analysis.

$\ddagger$ Other possible location is at $12.9 \mathrm{~kb}$.

$\S$ Position not certain because fragment lacks internal sites of other mapped enzymes.

The mapping strategy employed was double digests of all enzymes with BglII and with ClaI to produce a crude map. All warbler mtDNAs contained a single $C l a I$ site and two or three $B g / \mathrm{II}$ sites. The ClaI site appears to be conserved in all warblers examined in this study (see below). Additional double and triple digests with other enzyme combinations were then used to determine more precisely the relative site positions.

Maps of yellow warbler and outgroup mtDNAs were aligned with the single $C l a I$ site. This site appears to be conserved in warblers, in other passerines examined in this lab (including Coerebidae: Coereba, and Estrildidae: Vidua, Pytilia, Hypargos, and Lagonosticta; Klein pers. obs.), and in the chicken, Gallus gallus (Desjardins and Morais 1990). This ClaI site is found also in higher primates, rodents, ungulates, and bats (Bibb et al. 1981; Anderson et al. 1982; Carr et al. 1986; Hixson and Brown 1986; Phillips et al. 1991). Homology of the conserved ClaI site in yellow warblers and all outgroup taxa was confirmed by its constant position relative to two SacII sites that mark a $1.72-\mathrm{kb}$ fragment and that are highly conserved among vertebrate mtDNAs (Brown 1985; Carr et al. 1987; Moritz et al. 1987). One $\mathrm{SacII}$ site is located within the $12 \mathrm{~S}$ ribosomal RNA (rRNA) gene, the other in the 16S rRNA gene (Hixson and Brown 1986; Desjardins and Morais 1990). ClaI cleaved this $1.72-\mathrm{kb}$ fragment into a $1.4-\mathrm{kb}$ and a $0.32-\mathrm{kb}$ fragment in the mtDNA of all warblers examined, and a ClaI site is found in the published chicken mtDNA sequence, between the SacII sites, 332 bp (within the range of measurement error of the $320 \mathrm{bp}$ fragment found in the warbler mtDNAs) from the SacII site in the 12S rRNA gene.
Sequence divergence between pairs of mtDNA haplotypes was estimated from cleavage map comparisons using equations (21) and (28) of Nei and Tajima (1983). Estimates of divergence were calculated separately for each type of enzyme (6base, 6-base degenerate, or 5-base degenerate) with the final estimate a weighted average of these values (weighted in accordance with the total number of base pairs recognized by each enzyme type).

The matrix of cleavage-site presence/absence was used to generate hypotheses of relationship among yellow warbler mtDNAs. Individual haplotypes were the operational taxonomic units (OTUs). Because vertebrate mtDNA probably is transmitted across generations without recombination (Brown 1983, 1985; Moritz et al. 1987), there is a direct ancestor-descendent relationship. Treating haplotypes as OTUs means that a given population may consist of more than one OTU, and one OTU can span several populations.

Evolutionary trees were generated by parsimony analysis using PAUP version 3.0s (Swofford 1991). Ten heuristic searches were completed, using the random addition sequence and tree bisection-reconnection branch swapping options. All six outgroup species were included in the analysis without specifying relationships among them. Results presented are those generated when haplotype CA-B was excluded from the phylogenetic analyses (fig. 3), and those generated when haplotypes CA-B and CA-J were excluded (fig. 4). These haplotypes were excluded because each differed from another Central American haplotype by single site losses and their inclusion resulted in a large increase in the num- 
TABLE 2. Haplotypes and fragment patterns (indicated by letters) and locality where sampled. Locality abbreviations as in figures 1 and 2. Enzyme order: $A v a \mathrm{I}, A v a \mathrm{II}, B a m H I, B c l \mathrm{I}, B g l \mathrm{II}, B s t E \mathrm{II}, C l a \mathrm{I}, H i n d I I I, K p n I$, NdeI, NheI, PvuII, SpeI.

\begin{tabular}{|c|c|c|c|}
\hline Haplotype & Fragment patterns & $N$ & Localities $(N)$ \\
\hline \multicolumn{4}{|l|}{ West Indies } \\
\hline WI-A & AAAAAAAAAAAAA & 52 & $\begin{array}{l}\text { DR (6), PR (10), ST (5), SJ (8), SC (8), } \\
\text { MO (8), GU (2), DO (1), SL (4) }\end{array}$ \\
\hline WI-C & AGAAAAAAAAAAA & 5 & DR (1), PR (3), ST (1) \\
\hline $\mathrm{CA}-\mathrm{F}^{*}$ & AAABBAAAABAAA & 2 & DR (2) \\
\hline WI-E & AAAAAAADAAAAA & 1 & DR (1) \\
\hline WI-F & AAAACAAAAAAAA & 6 & PR (4), SJ (1), SC (1) \\
\hline WI-G & BBABBCABAAADB & 11 & GU (2), DO (5), MA (4) \\
\hline WI-B & BBABBCABCAADB & 1 & GU (1) \\
\hline WI-H & ADABBAAAAAAAA & 2 & $\mathrm{JA}(2)$ \\
\hline WI-I & ACCBBAAAAAAAA & 5 & JA (5) \\
\hline WI-J & ACCBBAAAAAADC & 2 & $\mathrm{JA}(2)$ \\
\hline WI-K & CAABBAAAAAAAA & 1 & FL (1) \\
\hline \multicolumn{4}{|c|}{ Central America } \\
\hline CA-A & CВABBBABABAAA & 11 & CR (11) \\
\hline CA-B & CBABBBAEABAAA & 2 & CR (2) \\
\hline $\mathrm{CA}-\mathrm{C}$ & ABABBCABABAAA & 8 & $\mathrm{CR}(5), \mathrm{CPa}(2), \mathrm{PPa}$ (1) \\
\hline CA-D & ABABBCABAAAAA & 2 & PPa (2) \\
\hline CA-E & CHABBCABAAAAA & 1 & $\mathrm{PPa}(1)$ \\
\hline CA-F* & AAABBAAAABAAA & 5 & $\mathrm{CPa}(5)$ \\
\hline CA-G & ABABBBABABAAA & 1 & CR (1) \\
\hline CA-H & AAABBAAAABAAD & 1 & $\mathrm{CPa}(1)$ \\
\hline CA-I & CHABBBABABAAA & 1 & CR (1) \\
\hline CA-J & CBABBCABAAAAA & 1 & $\mathrm{CPa}(1)$ \\
\hline \multicolumn{4}{|l|}{ Venezuela } \\
\hline VE-A & BJBBBCABAAADB & 19 & $\operatorname{Moc}(7), \operatorname{Mor}(12)$ \\
\hline VE-B & AIABBEAAABAAA & 11 & Par (6), Anc (5) \\
\hline VE-C & BBABBCAAAAADA & 2 & Par (1), Anc (1) \\
\hline VE-D & AIABBEAAADAAA & 5 & Anc (5) \\
\hline VE-E & AAABBEAAABAAA & 2 & Anc (2) \\
\hline VE-F & BJBGBCABAAADB & $\overline{1}$ & $\operatorname{Moc}(1)$ \\
\hline \multicolumn{4}{|c|}{ North America } \\
\hline NA-A & AFBBBDABBCBFA & 22 & MI (13), NC (9) \\
\hline NA-C & AFBBBDACBCBFA & 1 & $\mathrm{MI}(1)$ \\
\hline NA-D & AFBBBDABBCCFA & 1 & MI (1) \\
\hline NA-E & AFBBBDAABCBBA & 1 & MI (1) \\
\hline NA-F & AEABBDABBCBFA & 1 & MI (1) \\
\hline NA-G & AFBBBCABBIBHA & 1 & Baja (1) \\
\hline NA-I & AFBBBCABBCBHD & 2 & WA (2) \\
\hline NA-J & AKBBBCABBCBHA & 1 & WA (1) \\
\hline NA-L & AFBBBCABBKBHD & 1 & WA (1) \\
\hline NA-M & AFBBBCABBLBHA & 1 & WA (1) \\
\hline NA-N & AFBBBCAFBJBHD & 1 & WA (1) \\
\hline
\end{tabular}

* Ca-F found in West Indies and Central America.

ber of equally parsimonious trees. Inclusion/exclusion of CA-B and CA-J resulted in essentially the same topologies; that is, they were placed in an unresolved group of Central American haplotypes and branching patterns in the rest of the tree were unaffected by their presence/absence. To reduce computer run time, subsequent searches were therefore conducted without CA-B and CA-J. These searches were those done under various topological constraints to test the mono- phyly of different groups of haplotypes. Because using only $D$. pensylvanica as the outgroup resulted in the same number of most parsimonious trees and ingroup topologies as did use of all six outgroup species together, the tests of monophyly of different haplotype groups were done with only $D$. pensylvanica as the outgroup.

The statistical significance of differences between the shortest tree and those trees generated under topological constraints was evaluated with 
TABle 3. Mean and standard deviation of size estimates (in kb) of mitochondrial DNA molecules of warbler species.

\begin{tabular}{lcc}
\hline \hline \multicolumn{1}{c}{ Species } & Mean & SD \\
\hline Dendroica petechia & 17.1 & 0.13 \\
D. pensylvanica & 17.0 & 0.20 \\
D. discolor & 17.0 & 0.15 \\
Setophaga ruticilla & 17.1 & 0.16 \\
Parula americana & 17.0 & 0.09 \\
Geothlypis trichas & 17.0 & 0.25 \\
Basileuterus culicivorus & 17.2 & 0.24 \\
\hline
\end{tabular}

the nonparametric method of Templeton (1983b). Because this test cannot be done on consensus trees, tree number seven from each constrained analysis was arbitrarily selected for comparison with tree number seven from the unconstrained analysis.

To make inferences about the evolution of migratory behavior within yellow warblers, an additional parsimony analysis was done, adding migratory behavior as a character and including all outgroup species. Of the latter, only $B$. culicivorus is sedentary. Because the topology of the trees summarized in a consensus was essentially the same as that generated by analysis of DNA data alone, only simplified versions of the trees are shown (fig. 5).

\section{RESULTS}

Haplotype Distributions. - Thirty-seven yellow warbler haplotypes were identified after digestion with 13 restriction endonucleases (table 2). Outgroups were intraspecifically monomorphic with respect to mtDNA haplotypes, but sample sizes were small and each species was represented by single-locality samples only. One hundred and eighteen restriction sites were surveyed (51-62 per individual), 41 of which were restricted to outgroup species. Twenty-nine sites were phylogenetically informative within yellow warblers. The mapped positions of sites and their presence/absence in each haplotype are listed in table 1 .

Size estimates of the mtDNA molecules were similar for all species (table 3 ), similar to those previously reported for warblers (Kessler and Avise 1985), and within the range reported for other birds (Shields and Helm-Bychowski 1988).

Estimated pairwise sequence divergence among yellow warbler $\mathrm{mtDNAs}$ ranged from $0.14-3.17 \%$ (mean: $1.5 \%$ ), and that between mtDNAs from yellow warblers and the other warbler species used as outgroups ranged from 2.87 to $8.53 \%$.

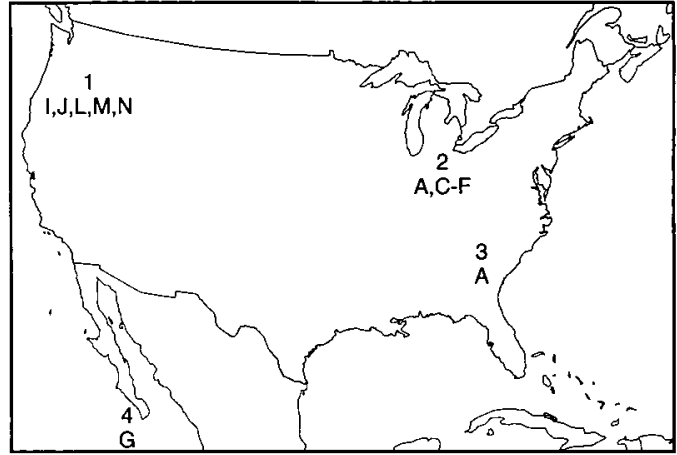

Fig. 1. Distribution of North American (NA-) haplotypes. Numbers refer to these general localities: 1, Washington (WA); 2, Michigan (MI); 3, North Carolina (NC); 4, Baja California (Baja).

Genetic discontinuity on a large geographic scale in the yellow warbler is suggested by the regionally limited distributions of most haplotypes. Although some of the West Indian and Venezuelan haplotypes (WI-G, WI-B, VE-A, VEF) shared more cleavage sites with each other than they did with other haplotypes in their respective regions, only one haplotype (CA-F) was found in more than one of the four geographic regions studied (North America, Central America, Venezuela, and West Indies) (table 2). CA-F was found in the West Indies (Dominican Republic) and in Central America (on islands off the Caribbean coast of Panama at Bocas del Toro).

Haplotypes also often had limited geographic distributions within a region (figs. 1,2 ), but differences between the most common haplotype and others within a region were usually only one or two restriction-site gains/losses.

Phylogenetic Analyses. - When CA-J was included and CA-B excluded from the analysis, in excess of 3000 shortest trees were generated on the first replication in PAUP. A subsequent run was then undertaken in which no more than 100 trees of minimum length were saved from each replication, resulting in 500 most parsimonious trees, 165 steps each (fig. 3). When CA-J was also excluded, 105 trees of 164 steps each were retained after ten replications (fig. 4), saving a maximum of 1000 trees per replication.

A major split divides the North American (NA-) haplotypes (including NA-G from a tropical sedentary population in Baja California) from the rest, which are all from tropical sedentary populations in Venezuela, Central America, and the West Indies. This North American clade is 


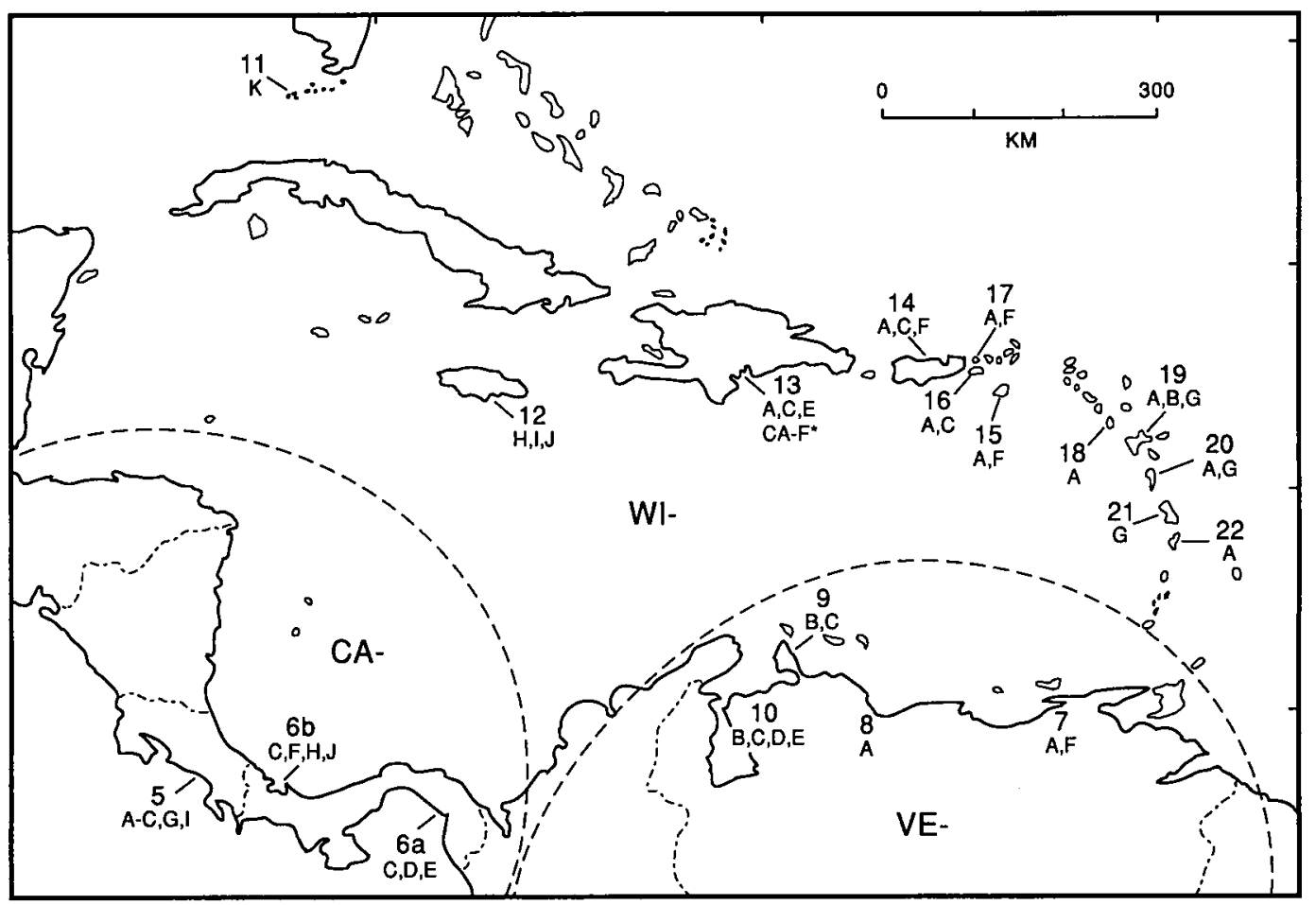

FIG. 2. Distribution of haplotypes from tropical populations. Numbers refer to these general localities: 5, Costa Rica (CR); 6a, Pacific coast; Panama (PPa); 6b, Caribbean coast, Panama (CPa); 7, Venezuela, Mochima (Moc); 8, Venezuela, Morrocoy (Mor); 9, Venezuela, Paraguana (Par); 10, Venezuela, Ancon de Iturre (Anc); 11, Florida Keys (FL); 12, Jamaica (JA); 13, Dominican Republic (DR); 14, Puerto Rico (PR); 15, St. Croix (SC); 16, St. Thomas (ST); 17, St. John (SJ); 18, Montserrat (MO); 19, Guadeloupe (GU); 20, Dominica (DO); 21, Martinique (MA); 22, St. Lucia (SL).

supported by one restriction-site gain and two site losses. Little resolution exists within North America, except that haplotypes from Washington state and Baja California form a group supported by two restriction-site gains (fig. 3).

Within the tropics, haplotypes from within regions (Central America, West Indies, Venezuela) did not form monophyletic groups. Although sequence divergence among Central American haplotypes was low (mean pairwise divergence of $0.56 \%$, range: $0.16-1.14 \%$ ), two of the haplotypes (CA-F and CA-H) were united with some West Indian and Venezuelan haplotypes to the exclusion of the others from Central America (figs. 3, 4). Three extra steps are required for monophyly of Central American haplotypes, but the difference between the most parsimonious tree and the constrained tree is not statistically significant (table 4).

West Indian haplotypes (WI-) were divided among two clades. One, identified in all trees, consisted of two Lesser Antillean haplotypes (WI-G and WI-B) and three Venezuelan haplotypes (VE-A, VE-F, and VE-C) (figs. 3, 4). Another, identified in $57 \%$ of the shortest trees, consisted of the rest of the West Indian haplotypes except CA-F (fig. 4). Within this clade, WI-A (which was the most common and widespread of all West Indian haplotypes) formed a group with three other haplotypes probably derived from it. Haplotypes from Jamaica formed a group within this larger West Indian assemblage. Monophyly of West Indian haplotypes requires seven extra steps, and the difference between the most parsimonious tree and the constrained tree is statistically significant (table 4).

Venezuelan haplotypes (VE-) were also divided among two clades, the one mentioned above (with Lesser Antillean haplotypes), and one with some Central American haplotypes (identified in $71 \%$ of the trees) (figs. 3, 4). Monophyly of Venezuelan haplotypes requires seven extra steps and 


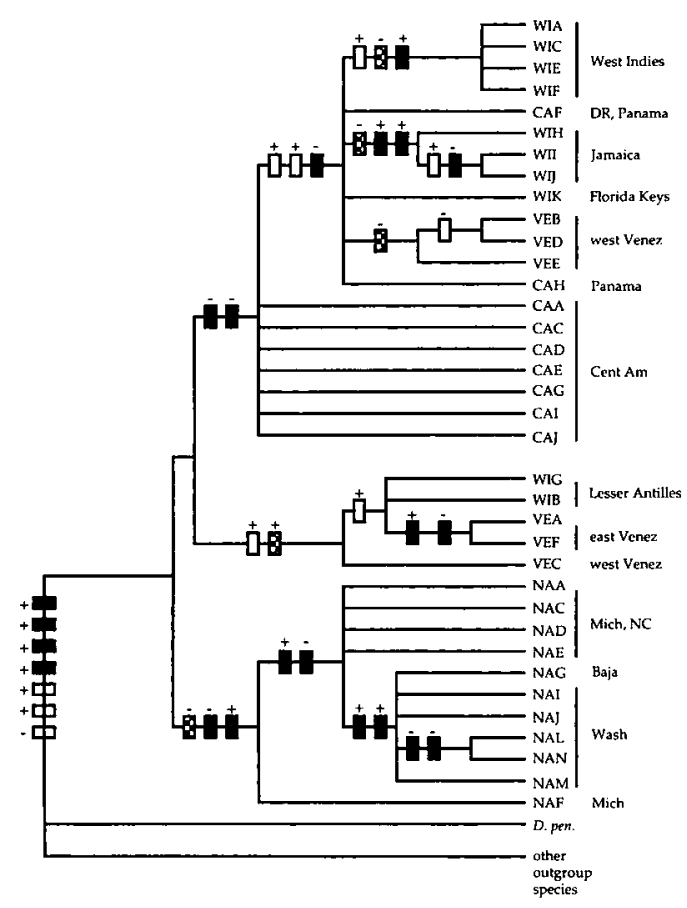

FIG. 3. Strict consensus of 500 most parsimonious trees. Length $=165$ steps. Includes haplotype CA-J. $\mathrm{CI}=0.48, \mathrm{HI}=0.52$ (excluding uninformative characters), $\mathrm{RI}=0.79, \mathrm{RC}=0.48 .+/-$, gain/loss of restriction site. White bar, unique synapomorphy; solid black bar, homoplastic synapomorphy; checkered bar, unique synapomorphy relative to ingroup only.

the difference between the constrained tree and the most parsimonious tree is statistically significant.

\section{Discussion}

Intraspecific Genetic Divergence and Hierarchical Structure.-As indicated by the trees obtained from parsimony analysis and summarized in the consensus topology (figs. 3, 4), some haplotypes (and populations) within Dendroica petechia, share a much more recent common ancestor than do others. Some other avian species show such phylogenetic structure (Mack et al. 1986; Shields and Wilson 1987; Avise and Nelson 1989; Van Wagner and Baker 1990; Zink 1991; Gill and Slikas 1992; Seutin et al. 1993), but many do not (Ball et al. 1988; Shields and Helm-Bychowski 1988; Fleischer et al. 1991; Moore et al. 1991; Ovendon et al. 1991; Zink et al. 1991; Hare and Shields 1992).

The range of estimated sequence divergence values between pairs of haplotypes in yellow war-

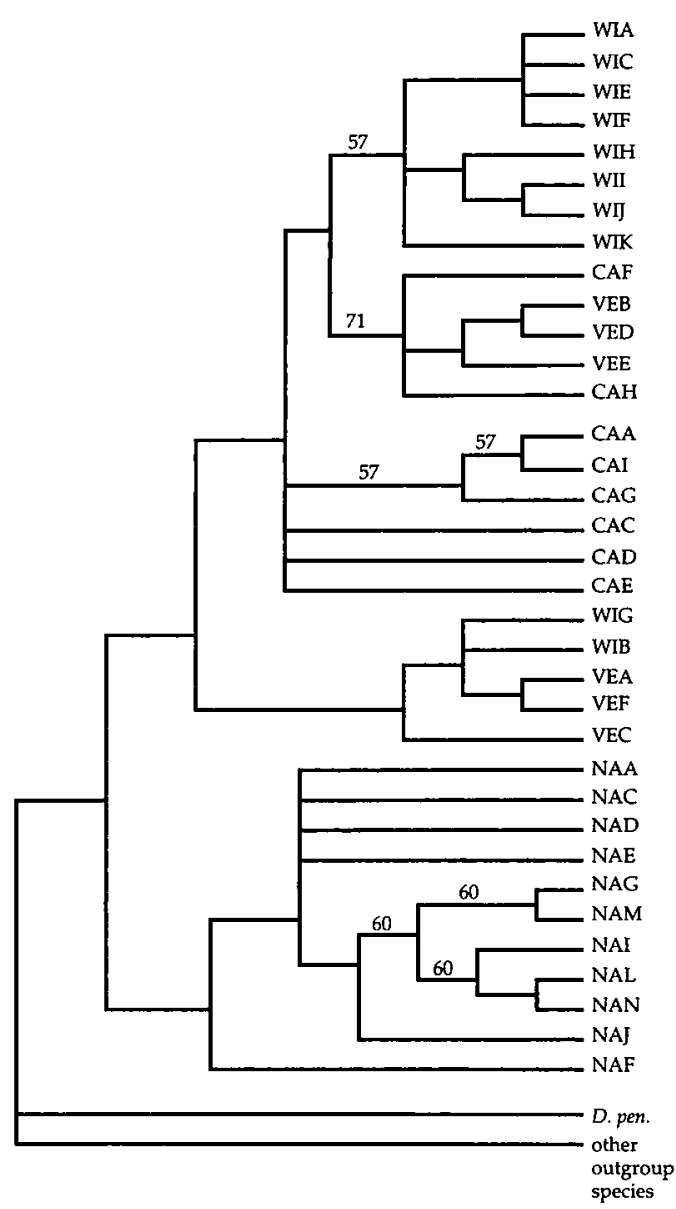

FIG. 4. Majority-rule consensus of 105 trees. Length $=164$ steps. Excludes haplotype CA-J. Numbers, \% of trees with that node. No numbers, node appeared in $100 \%$ of trees. $\mathrm{CI}=0.48, \mathrm{HI}=0.52$ (excluding uninformative characters), $\mathrm{RI}=0.79, \mathrm{RC}=0.49$.

blers (0.14-3.17\%) also suggests a temporal component to intraspecific diversity. Molecular (DNA) divergence may not be completely metric (DeSalle and Templeton 1987; Templeton 1987; Vawter and Brown 1986), yet a positive correlation has been demonstrated between genetic divergence and temporal divergence (time since splitting) (Farris 1981; Brown 1983; Wilson et al. 1985; Ayala 1986; Moritz et al. 1987). Although migratory populations that nest in North America have at times been considered a separate species (D. aestiva) (Hellmayr 1935) and should perhaps still be so classified (Ridgely 1976), substantial variation in intraspecific divergence is found even among haplotypes sampled only from sedentary tropical populations (0.14-2.22\%). 
TABLE 4. Wilcoxon matched-pairs signed ranks test (two-tailed) of a most-parsimonious tree with no topological constraints (67 steps) compared with other hypotheses of relationship (with topological constraints). Tree A, Central American haplotypes monophyletic; tree B, West Indian haplotypes monophyletic; tree $C$, Venezuelan haplotypes monophyletic; tree $D$, Tropical haplotypes (including NA-G) monophyletic and North American haplotypes (migratory populations) monophyletic; tree E, all regions monophyletic. For all analyses, multiple shortest trees of equal length were generated. Therefore, one tree from each analysis (arbitrarily chosen to be tree 7) was used for the comparisons. All trees compared were those generated using only Dendroica pensylvanica as the outgroup. For the two topologies being compared, "No. of sites" is the number of restriction sites that undergo the greater $(+)$ or lesser $(-)$ number of changes listed in the corresponding score column; "score" is the greater $(+)$ or lesser $(-)$ number of changes each site undergoes on the alternative tree relative to the most parsimonious tree; and rank is the relative rank of the scores for each of those sites. $T$ is the test statistic, the sum of the negative ranks. The absence of negative scores or ranks for all comparisons suggests the most parsimonious tree is equally or more compatible with the data sets than are any of the alternative trees, and is significantly more compatible for all comparisons except that with trees $\mathrm{A}$ and $\mathrm{D}$.

\begin{tabular}{lcccccc}
\hline \hline \multicolumn{7}{c}{ No. of } \\
\multicolumn{2}{l}{ Tree Length } & Sites & Score & Rank & $T$ & $P$ \\
\hline A & 70 & 3 & +1 & 2 & 0 & $>0.10$ \\
B & 74 & 5 & +1 & 3 & 0 & $<0.04$ \\
& & 1 & +2 & 6 & & \\
C & 74 & 5 & +1 & 3 & 0 & $<0.04$ \\
& & 1 & +2 & 6 & & \\
D & 73 & 4 & +1 & 2.5 & 0 & $<0.06$ \\
& & 1 & +2 & 5 & & \\
E & 86 & 4 & +1 & 2.5 & 0 & $<0.01$ \\
& & 4 & +2 & 6.5 & & \\
& & 1 & +3 & 9 & & \\
& & 1 & +4 & 10 & & \\
\hline
\end{tabular}

Phylogenetic Relationships among Populations. - The haplotypes sampled form two groups in the parsimony analysis: North American haplotypes versus most of those from tropical resident populations. Differentiation of North American migratory populations from sedentary, tropical populations is not surprising because their breeding ranges do not overlap, and gene flow between them is presumably negligible. It is surprising, however, that the Baja California haplotype (NA-G) is part of this assemblage, since the population sampled is sedentary and tropical, with a plumage pattern nearly identical to that of Central American sedentary birds and different from that of North American migratory birds. Constraining the tree such that all haplotypes from tropical sedentary populations (including NA-G) form a monophyletic group distinct from a monophyletic group of haplotypes from North American migratory populations requires six extra steps (table 4). Given the conservative nature of the two-tailed test, the difference between the constrained and the most parsimonious tree $(P$ $<0.06$ ) is probably significant.

It is also surprising that NA-G is placed in the middle of the North American group, making the migratory populations paraphyletic. However, because monophyly of the haplotypes from migratory populations (with NA-G as the sister taxon to them) requires only one extra step, support for this paraphyletic arrangement is not strong.

Within North America, some hierarchical structure exists among haplotypes from migratory populations of yellow warbler. Haplotypes from Washington state (NA-I, J, L, M, N) form a group (with NA-G) within the larger North American assemblage. North Carolina birds all shared the same haplotype, which was also the most common one in Michigan (NA-A). Genetic differentiation of Washington state birds relative to those from Michigan and North Carolina is consistent with their placement in currently recognized subspecies (D. p. morcomi for Washington, D. p. aestiva for Michigan and North Carolina). Mitochondrial DNA markers identifying regional breeding locality may thus exist for temperate-zone populations of this species, although more widespread sampling must be done to verify the possibility.

Although all but one of the mtDNA lineages within the tropical distribution are endemic to the regions where sampled, they do not cluster in distinct regional groups. Several alternative hypotheses can explain the lack of regional monophyly in yellow warbler mtDNAs: the occurrence of past or present gene flow and introgression of mtDNA (Takahata and Slatkin 1984; Tegelstrom 1987), divergence between regional populations too recent for mtDNA lineages to be sorted into monophyletic groups (Tajima 1983; Avise et al. 1984; Neigel and Avise 1986; Takahata 1989; Wu 1991), or parallel evolution of mtDNA (i.e., homoplasy of restrictionsite gains or losses) (Aquadro and Greenberg 1983; Templeton 1983a; Moritz et al. 1987). The mtDNA data themselves do not allow testing of the alternative hypotheses for mtDNA genealogic relationships that may or may not be concordant with population phylogenies (Ball et al. 
1990). Additional data are necessary, for example, phylogeny estimates based on additional independent characters, or examination of geographic patterns in phenotypic characters. Such data exist for some instances of nonmonophyly in yellow warblers (see below), but not for others. Substantial ongoing gene flow among regions is assumed to be negligible because of the marked morphological and behavioral differences among birds from the different regions, dispersal barriers between regions, and (with the exception of CA-F) the lack of any mtDNA haplotype being sampled from more than one region.

The presence of haplotype CA-F on Hispaniola and on Caribbean islands off the coast of Panama (Bocas del Toro) is puzzling because these localities are separated by $1500 \mathrm{~km}$ of open water and because phenotypic (especially plumage) differences between the two populations are marked. Possible explanations are introgression of $\mathrm{mtDNA}$, retention of ancestral polymorphism in mtDNA, parallel evolution of mtDNA, or multiple colonizations of Hispaniola coupled with rapid phenotypic evolution and/or selection against males descended from mainland founders. Passage of hurricanes through the region could present the opportunity for unusual dispersal and thus introgression of mtDNAs. Retention of ancestral polymorphism is also possible but unlikely for island populations, which have probably experienced founder effects at colonization, as well as post-colonization bottlenecks. It is estimated to take $4 N(N=$ number of females in the founding population) generations for all individuals within a population to trace the origin of their mtDNAs to a single ancestral haplotype (Tajima 1983; Avise et al. 1984; Neigel and Avise 1986). If a population bottleneck (e.g., founder event) reduces the effective female population size to a small number, time to monophyly of population mtDNAs would be short and the presence of divergent mtDNAs within a population would be unlikely to represent retention of ancestral polymorphism (Tajima 1983). It is interesting to note that in $71 \%$ of the shortest trees, CA-F and CA-H, which are from the Caribbean coast of Panama, cluster with haplotypes from coastal Venezuela instead of those from the Pacific coast of Central America.

Haplotypes from Jamaica (WI-H, WI-I, WIJ) form a monophyletic group within a larger West Indian assemblage. Monophyly of Jamaican taxa also has been demonstrated for Eleutherodactylus frogs (Hedges 1989), but not for bats of the species Artibeus jamaicensis (Phillips et al. 1989). The range of estimated sequence divergences between Jamaican yellow warbler haplotypes and those from other West Indian localities $(0.30-1.85 \%)$ either suggests that the population on that island has been isolated from those on some other islands for a long period or that it was colonized by a different source population than were some other islands. Although relationships among Jamaican haplotypes and those from most Caribbean islands are unresolved for yellow warblers, Jamaican populations of many other organisms, including birds, have been suggested as the colonization sources for some other islands (Bond 1963, 1978; Baker and Genoways 1978; Brown 1978). During Pleistocene glaciations, Jamaica was much closer to the Central American mainland than at present, and it was the closest of any of the Greater Antilles because of lower sea levels (Heatwole and MacKenzie 1967; Buskirk 1985).

The presence in the Lesser Antilles of two very divergent groups of haplotypes (WI-A, C, E, F vs. WI-B, G) that do not cluster as a monophyletic assemblage suggests multiple colonizations of the West Indian archipelago and of at least two individual islands. Haplotype WI-A is widespread throughout the Caribbean region (on 9 of the 12 islands sampled). Most other haplotypes sampled from localities where WI-A was found probably were derived from it because these haplotypes (WI-C, WI-E, WI-F) differ from WI-A by only one or two restriction-site gains or losses. Haplotype WI-G, from the Lesser Antilles, is separated from WI-A by nine restriction-site changes ( $1.35 \%$ sequence divergence). WI-B differs from $G$ by a single autapomorphous restriction-site loss, and both are similar to the Venezuelan haplotypes VE-A and VE-F (0.29-0.58\% sequence divergence). In the parsimony analysis WI-B and G form a monophyletic group with VE-A and F, not with other West Indian lineages. Venezuelan populations (or their ancestors) were thus the most likely colonization sources of some of the present-day Lesser Antillean populations. The grouping of WI-G and WI-B with VE-A and VE-F and, thus, polyphyly of West Indies yellow warblers, is supported by three site gains uniquely synapomorphic within yellow warblers. An hypothesis of multiple colonization is also supported by patterns of geographic variation in plumage. Plumage color pattern of Martinique birds (haplotype WI-G, subspecies $D$. p. ruficapilla) is very similar to that of Venezuelan pop- 
ulations at Morrocoy and Paraguana (haplotypes VE-A, VE-B, and VE-C, subspecies D. p. cienegae and D. p. paraguanae) and different from that of other West Indian birds (Hellmayr 1935; Klein 1992). As discussed above, retention of ancestral polymorphism is an unlikely explanation for the presence of very divergent haplotypes in the West Indies, because the populations involved are on islands colonized by overwater dispersal and, thus, are subject to founder effects and population bottlenecks.

The presence within islands of haplotypes belonging to different clades suggests multiple colonizations of some individual islands. Both WI-G and WI-A are found on Dominica and Guadeloupe, the two islands north of Martinique. Only WI-A was found on St. Lucia, the adjacent island south of Martinique, and on Montserrat, the adjacent island north of Guadeloupe. Even though sample sizes were small for St. Lucia $(N=4)$ and Martinique $(N=4)$ and both haplotypes may exist on them, this hypothesis of historical relationship among island populations is supported by patterns of plumage variation among the individuals sampled (Klein 1992). Populations on Dominica and Guadeloupe have been described as a recognizable taxon (subspecies $D . p$. melanoptera) and many individuals have a plumage pattern intermediate to that of most other West Indian birds and that of Martinique birds (Klein 1992). St. Lucia birds (haplotype WI-A) are more similar in appearance to populations on islands north of Guadeloupe (Klein 1992) and which also possess only WI-A and closely related haplotypes. Multiple colonizations of individual islands and a similar pattern in which one group of related haplotypes is widespread in the West Indies and another is confined to the Lesser Antilles also have been demonstrated for bats (Pumo et al. 1988; Jones 1989; Phillips et al. 1989).

In the phylogenetic analysis, Venezuelan haplotypes (VE-) also clustered into two groups. Each group formed a clade with a different set of nonVenezuelan haplotypes, some of which were derived relative to those from Venezuela. Venezuelan haplotypes were thus polyphyletic and paraphyletic. The groups are (1) haplotypes (VE-A and VE-F) from the two easternmost localities (Mochima and Morrocoy) plus one (VE-C) from the westernmost localities (Paraguana and Ancon de Iturre), and (2) the remaining haplotypes (VE-B, VE-D, and VE-E) from Paraguana and Ancon de Iturre. Possible explanations for the relatively high levels of divergence between eastern and western localities (mean estimated sequence divergence of $1.80 \%$ ) are (1) a past barrier (vicariance event) divided an ancestral Venezuelan population into two geographically isolated units corresponding to the two groups of lineages, which have subsequently diverged genetically; or (2) an ancestral population was polymorphic and the polymorphisms have since sorted along geographic lines. The present data do not allow discrimination among these possibilities. The more basal position of one "western" haplotype (VE-C) relative to the two "eastern" haplotypes suggests that haplotypes in the eastern localities may be derived from those in western localities. Currently all of these populations are isolated from each other by barriers of unsuitable habitat and, because plumage and morphometric traits differ among them (Wiedenfeld 1991; Klein 1992), present-day gene flow is probably negligible.

Evolution of Migration.-Models of the evolution of migration systems in the New World avifauna invoke multiple causative factors (reviewed in Cox 1985). All assume migratory behavior evolved in sedentary populations, and that each migratory species represents a separate data point, that is, that migratory behavior evolved more than once, even within clades. Optimization of migratory behavior on one of the randomly selected shortest trees depicting yellow warbler relationships (summarized in fig. 5 , tree 1) suggests migratory behavior is the plesiomorphic state in this species and that sedentary behavior evolved twice from migratory ancestors. Optimization on one of the randomly selected trees that is constrained to make migratory populations form a monophyletic group (one step longer than the shortest trees) suggests either plesiomorphy of migratory behavior with multiple origins of sedentary behavior (fig. 5 , tree $2 b$ ), or a single origin of migratory behavior from a sedentary ancestor within yellow warblers (fig. 5, tree 2a).

Caribbean Biogeography.-Although much has been published on the historical biogeography of nonavian taxa in the Caribbean (Rosen 1975; Guyer and Savage 1986; Kluge 1988; Rauchenberger 1988; Burgers and Franz 1989; Phillips et al. 1989; Woods 1989; Hass 1991), comparatively little has been written about the origins of West Indian bird species (Bond 1963, 1978; Cruz 1974; Olson 1976, 1978). Many examinations of ecological factors and their effects on 
1

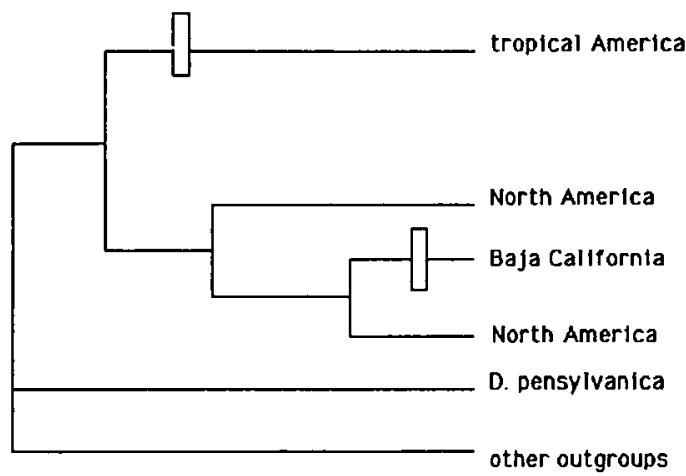

$2 a$

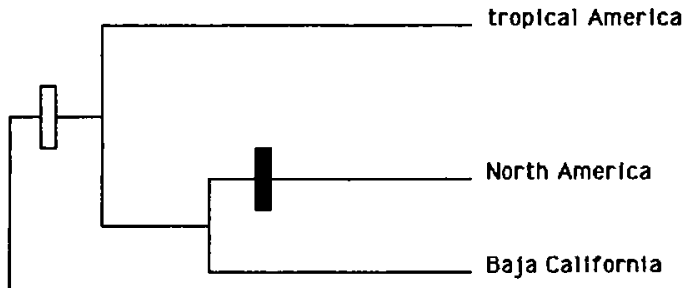

D. pensylvanica

other outgroups

$2 b$

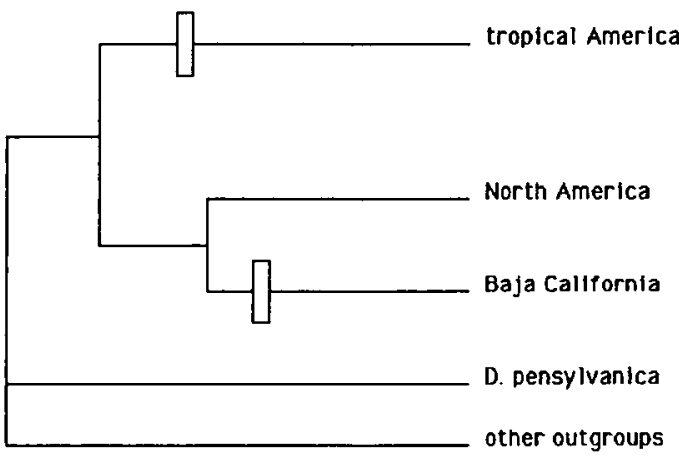

FIG. 5. Optimization of migratory behavior on tree topology (simplified for illustration) generated from analysis of restriction site and migratory behavior characters. Black bars, gain of migratory behavior. White bars, loss of behavior. Tree 1: ACCTRAN and DELTRAN optimization on shortest tree; Tree 2a: ACCTRAN optimization on tree one step longer than shortest tree; Tree 2b: DELTRAN optimization on tree one step longer than shortest tree. All outgroups except bird distributions exist (Ricklefs and Cox 1972, 1978; Lack 1973, 1976; Terborgh et al. 1978; Faaborg 1985), but no explicit hypotheses of historical (phylogenetic) relationships among West Indian avian taxa have yet been published (but see McDonald and Smith 1990). A historical perspective is essential for understanding presentday distributions (Pregill and Olson 1981; Endler 1982).

Although vicariance models have been proposed for the origins of West Indian taxa (Rosen 1975; Kluge 1988), these probably have little bearing on the distribution of yellow warblers, as well as other passerines in the region. Fossil evidence for the time of origin of passerine birds is scanty, but the group is thought to have appeared at the beginning of the Miocene (Brodkorb 1971). The West Indies are thought to have assumed their present positions and configuration by the beginning of the Miocene (Donnelly 1988), leaving little possibility for a vicariant origin for taxonomically differentiated populations of warblers.

Previous hypotheses for the origins of West Indian birds have been based on subjective analyses of similarities among extant mainland and island taxa (Bond 1963, 1978), as well as of fossilized remains (Olson 1978). Bond (1963, 1978) postulated two main sources of colonization: from South America to the Lesser Antilles, and from North America (including Mexico and Central America) to the Greater Antilles via Jamaica or Cuba. These colonization routes have been proposed for nonavian taxa as well (Baker and Genoways 1978; Brown 1978; Koopman 1989). Colonization of the Greater Antilles by some North American avian taxa is also supported by paleontological evidence (Olson 1976, 1978). The phylogenetic hypothesis based on yellow warbler mtDNAs is consistent with the model of multiple colonizations, and with colonization sources proposed by Bond $(1963,1978)$ for widespread Caribbean birds, that is, colonization of some Lesser Antilles by Venezuelan birds, and colonization of the Greater Antilles by Central American birds.

Documentation of multiple colonizations of archipelagoes in general, and the West Indies in particular, has several important implications.

$\leftarrow$ Basileuterus are migratory; all North American pop-
ulations are migratory except that in Baja California. 
The most general is the effect of multiple colonizations (and thus the potential for introgression of characters) on phylogenetic inference. The problem is particularly acute when the characters sampled are portions of DNA that are nonrecombining and uniparentally transmitted across generations (Doyle 1993). The "foreign" mtDNA can be introgressed into a host population (Ferris et al. 1983; Powell 1983; Tegelstrom 1987), and this can occur without accompanying introgression of phenotypic traits (Smith 1992). Through the stochastic lineage sorting process (Tajima 1983; Avise et al. 1984; Neigel and Avise 1986), or through the active process of selection (Clark and Lyckegaard 1988), the introgressed DNA may become fixed within the host population. Use of the introgressed characters to infer phylogeny may thus result in an erroneous reconstruction of historical relationships among taxa. Although we were able to infer multiple colonizations of individual islands by yellow warblers, and have evidence of introgression (intermediate phenotype), one's future ability to recover this history would be compromised if one or the other of the "ancestral" haplotypes on Dominica or Guadeloupe were to become lost from these populations. Whether other species have invaded the Caribbean archipelago multiple times remains to be investigated.

Documentation of multiple colonizations also has implications for inferences about avian biogeography in the Caribbean. Ricklefs and Cox $(1972,1978)$ interpret patterns of geographic distribution and taxonomic differentiation of West Indian birds as reflecting the passage of species through stages of a taxon cycle. Widespread, undifferentiated species are suggested to be in the beginning stage of the cycle, and endemic, welldifferentiated species are considered to be at the end of the cycle. They suggest the ultimate cause of such a cycle is competition-driven, increasing specialization correlated with time since colonization of the archipelago. However, any test of this model must assume monophyly and thus a single colonization of the West Indies for the species being investigated.

Traditional avian biogeographic hypotheses for island faunas have assumed a stepping-stone method of dispersal as most likely (Darlington 1938; MacArthur and Wilson 1967; Ricklefs and Cox 1978), with colonization of an archipelago occurring only once and to the island nearest the mainland. The lack of resolution of relationships among most yellow warbler island populations does not allow direct testing of the stepping-stone colonization hypothesis for those islands. Nevertheless, because yellow warbler populations on some adjacent islands are not each others' closest relatives (e.g., St. Lucia vs. Martinique), our study suggests a stepping-stone model is not always correct, and this has implications for studies in ecology and evolution. In tracing the evolution of particular traits, the usual implicit assumption is that populations on adjacent islands are each others' closest relatives and that interisland phenotypic variation therefore is due to different selection pressures on different islands, or to stochastic processes like genetic drift; that is, phenotypic variation is assumed to have developed in situ (Ricklefs and Cox 1972). Previous authors (Hellmayr 1935; Bond 1939), for example, assumed that Martinique yellow warblers were most closely related to those on neighboring islands and that the striking plumage differences among island populations evolved in place. As indicated by the phylogenetic relationships of yellow warbler mtDNAs sampled from these islands, this assumption is incorrect. This is not to say, however, that stepping-stone colonization has not occurred in the West Indies, only that the assumption should be tested in any individual case.

\section{ACKNOWLEDGMENTS}

Funding for this research was provided by a National Science Foundation Dissertation Research grant BSR-881544S, the Frank M. Chapman Memorial Fund of the American Museum of Natural History, a Collection Study Grant from the American Museum of Natural History, the Sigma XI Scientific Research Society, the Hinsdale and Walker Fellowships of the Museum of Zoology, University of Michigan, Block Grants from the Department of Biology, University of Michigan, a Dissertation Research Grant from Rackham Graduate School, University of Michigan, and the Bird Division, Museum of Zoology, University of Michigan.

We thank the following for granting research/ collecting permits or for assistance and cooperation in acquiring specimens: $M$. Sc. Guillermo Canessa Mora, Servicio de Vida Sylvestre, Ministerio de Recursos Naturales, Energía, y Minas, Costa Rica; Dr. Giuseppe Colonello, Fundación La Salle de Ciencias Naturales, Venezuela; Gabriel Charles, Department of Forestry, St. Lucia; M. Benito-Espinal, Ministère de l'Équipement, du Logement, de l'Amenagement du Territoire et des Transport, Ministère Charge de l'Envi- 
ronnement, Guadeloupe, French West Indies; Loic Beroud, Préfecture de la Martinique, Direction Departementale de l'Agriculture, Martinique, French West Indies; Felix Gregoire and Colmore Christian, Forestry Division, Ministry of Agriculture, Commonwealth of Dominica; Ministry of Agriculture, Trade, Lands, and Housing, Montserrat; Alan Smith and David Nellis, Department of Planning and Natural Resources, Division of Fish and Wildlife, U.S. Virgin Islands; Emilio A. Bautista, Cecilia Hernandez, and Tom s Vargas, Departamento de Vida Silvestre, Secretaria de Estado de Agricultura, Dominican Republic; Yvette Strong and Dr. Somesh Sinha, Natural Resources and Conservation Division, Ministry of Agriculture, Jamaica; Dr. Eduardo Cardona, Departamento de Recursos Naturales, Puerto Rico; the U.S. Fish and Wildlife Service; the Michigan Department of Natural Resources; and the Division of Wildlife, Florida Game and Fresh-water Fish Division.

We thank all those who have helped with field work, especially M. Bon Saint Come, E. Benito Espinal, C. Gauveca, J. Gerwin, P. Hautcastel, Y. Klein, S. Lanyon, P. Lau, G. Rosenberg, K. Rosenberg, T. Schulenberg, T. Vargas, and J. Wunderle. Specimens from Panama were provided by M. Braun, G. Morton, T. Parsons, and D. Wiedenfeld; T. Peterson provided the specimen from Baja California; S. Rohwer and C. Wood provided specimens from Washington state. The computer program for calculating estimated sequence divergence was provided by $R$. Hagen. We thank P. Chu, J. Cracraft, M. Gach, N. Johnson, F. Kraus, A. Larson, M. C. McKitrick, P. Myers, R. B. Payne, G. Smith, and W. H. Wagner for their critical reviews of previous drafts of the manuscript. This paper was submitted by $\mathrm{N}$. Klein in partial fulfillment of the requirements for the Ph.D. in the Department of Biology, University of Michigan. Klein's dissertation chair, R. B. Payne, was especially helpful throughout all phases of this research.

\section{Literature Cited}

Anderson, S., M. H. L. deBruijn, A. R. Coulson, J. C. Eperon, F. Sanger, and I. G. Young. 1982. Complete sequence of bovine mitochondrial DNA: conserved features of the mammalian mitochondrial genome. Journal of Molecular Biology 156:684717.

Aquadro, C. F., and B. D. Greenberg. 1983. Human mitochondrial DNA variation and evolution: analysis of nucleotide sequences from seven individuals. Genetics 103:287-312.

Ashley, M., and C. Wills. 1987. Analysis of mito- chondrial DNA polymorphisms among channel island deer mice. Evolution 41:854-863.

Avise, J. C., and W. S. Nelson. 1989. Molecular genetic relationships of the extinct dusky seaside sparrow. Science 243:646-648.

Avise, J. C., J. E. Neigel, and J. Amold. 1984. Demographic influences on mitochondrial DNA lineage survivorship in animal populations. Journal of Molecular Evolution 20:99-105.

Avise, J. C., J. C. Patton, and C. F. Aquadro. 1980. Evolutionary genetics of birds. III. Comparative molecular evolution in New World warblers $\mathrm{Pa}$ rulidae) and rodents (Cricetidae). Journal of Heredity $71: 303-310$.

Ayala, F. J. 1986. On the virtues and pitfalls of the molecular evolutionary clock. Journal of Heredity 77:226-235.

Baker, R. J., and H. H. Genoways. 1978. Zoogeography of Antillean bats. Pp. 53-97 in F. B. Gill, ed. Zoogeography in the Caribbean. Proceedings of the Academy of Natural Sciences, Philadelphia Special Publication 13.

Ball, R. M., S. Freeman, F. C. James, E. Bermingham, and J. C. Avise. 1988. Phylogeographic structure of red-winged blackbirds assessed by mitochondrial DNA. Proceedings of the National Academy of Sciences, USA 85:1558-1562.

Ball, R. M., J. E. Neigel, and J. C. Avise. 1990. Gene genealogies within the organismal pedigrees of random-mating populations. Evolution 44:360-370.

Barrowclough, G. F., and K. W. Corbin. 1978. Genetic variation and differentiation in the Parulidae. Auk 95:691-702.

Berry, R. J. 1983. Diversity and differentiation: the importance of island biology for general theory. Oikos 41:523-529.

Bibb, M. J., R. A. Van Etten, C. T. Wright, M. W. Walberg, and D. A. Clayton. 1981. Sequence and gene organization of mouse mitochondrial DNA. Cell 26:167-180.

Bledsoe, A. H. 1988. Nuclear DNA and evolution and phylogeny of the New World nine-primaried oscines. Auk 105:504-515.

Bond, J. 1939. Notes on birds from the West Indies and other Caribbean islands. Notulae Naturae 13: $1-6$.

1948. Origin of the bird fauna of the West Indies. Wilson Bulletin 60:207-229.

- 1961. Sixth supplement to the check-list of birds of the West Indies (1956). Academy of Natural Sciences, Philadelphia.

- 1963. Derivation of the Antillean avifauna. Proceedings of the Academy of Natural Sciences, Philadelphia 115:79-98.

- 1978. Derivations and continental affinities of Antillean birds. Pp. 119-128 in F. B. Gill, ed. Zoogeography in the Caribbean. Proceedings of the Academy of Natural Sciences, Philadelphia Special Publications 13.

- 1979. Derivations of Lesser Antillean birds. Proceedings of the Academy of Natural Sciences, Philadelphia 131:89-103.

. 1993. A field guide to the birds of the West Indies. Houghton Mifflin, New York.

Brodkorb, P. 1971. Origin and evolution of birds. Avian Biology 1:19-55. 
Brown, F. M. 1978. The origins of the West Indian butterfly fauna. Pp. 5-30 in F. B. Gill, ed. Zoogeography in the Caribbean. Proceedings of the Academy of Natural Sciences, Philadelphia Special Publications 13.

Brown, W. M. 1980. Polymorphism in mitochondrial DNA of humans as revealed by restriction endonuclease analysis. Proceedings of the National Academy of Sciences, USA 77:3605-3609.

- 1983. Evolution of animal mitochondrial DNA. Pp. 62-88 in M. Nei and R. K. Koehn, eds. Evolution of genes and proteins. Sinauer, Sunderland, Mass.

-1985. The mitochondrial genome of animals. Pp. 95-130 in R. J. MacIntyre, ed. Molecular evolutionary genetics. Plenum, New York.

Brown, W. M., and J. Vinograd. 1974. Restriction endonuclease cleavage maps of animal mitochondrial DNAs. Proceedings of the National Academy of Sciences, USA 71:4617-4621.

Burgers, G. H. T., and R. Franz. 1989. Zoogeography of the Antillean freshwater fish fauna. Pp. 263-304 in C. A. Woods, ed. Biogeography of the West Indies: past, present, and future. Sandhill Crane Press, Gainesville, Fla.

Buskirk, R. E. 1985. Zoogeographic patterns and tectonic history of Jamaica and the northern Caribbean. Journal of Biogeography 12:445-461.

Carr, S. M., S. W. Ballinger, J. N. Derr, L. H. Blankenship, and J. W. Bickham. 1986. Mitochondrial DNA analysis of hybridization between sympatric white-tailed deer and mule deer in west Texas. Proceedings of the National Academy of Sciences, USA 83:9576-9580.

Carr, S. M., A. J. Brothers, and A. C. Wilson. 1987. Evolutionary inferences from restriction maps of mitochondrial DNA from nine taxa of Xenopus frogs. Evolution 41:176-190.

Clark, A. G., and E. M. S. Lyckegaard. 1988. Natural selection with nuclear and cytoplasmic transmission. III. Joint analysis of segregation and mtDNA in Drosophila melanogaster. Genetics 118:471-481.

Cox, G. W. 1985. The evolution of avian migration systems between temperate and tropical regions of the New World. American Naturalist 126:451-474.

Cruz, A. 1974. Distribution, probable evolution, and fossil record of West Indian woodpeckers (Family Picidae). Caribbean Journal of Science 14:183-188.

Darlington, P. J. 1938. The origin of the fauna of the Greater Antilles, with discussion of dispersal of animals over water and through air. Quarterly Review of Biology 13:274-300.

Desjardins, P., and R. Morais. 1990. Sequence and gene organization of the chicken mitochondrial genome. Journal of Molecular Biology 21 2:599-634.

DeSalle, R., and A. R. Templeton. 1987. Founder effects accelerate the rate of mitochondrial DNA evolution in Hawaiian Drosophila. Evolution 42: 1078-1084.

Donnelly, T. W. 1988. Geologic constraints on Caribbean biogeography. Pp. 15-37 in J. K. Liebherr, ed. Zoogeography of Caribbean insects. Cornell University Press, Ithaca, N.Y.

Dowling, T. E., and W. M. Brown. 1989. Allozymes, mitochondrial DNA, and levels of phylogenetic res- olution among four minnow species (Notropis: Cyprinidae). Systematic Zoology 38:126-143.

Dowling, T. E., C. Moritz, and J. D. Palmer. 1990. Nucleic acids II: Restriction site analysis. Pp. 250317 in D. M. Hillis and C. Moritz, eds. Molecular systematics. Sinauer, Sunderland, Mass.

Doyle, J. J. 1993. DNA, phylogeny, and the flowering of plant systematics. BioScience 43:380-389.

Eldredge, N., and J. Cracraft. 1980. Phylogenetic patterns and the evolutionary process. Columbia University Press, New York.

Endler, J. A. 1982. Alternative hypotheses in biogeography: Introduction and synopsis of the symposium. American Zoologist 22:349-354.

Faaborg, J. 1985. Ecological constraints on West Indian bird distributions. Pp. 621-653 in P. A. Buckley, M. S. Foster, E. S. Morton, R. S. Ridgely, and F. G. Buckley, eds. Neotropical ornithology. Ornithological Monographs 35.

Farris, J. S. 1981. Distance data in phylogenetic analysis. Advances in Cladistics 1:3-24.

Feduccia, A. 1977. A model for the evolution of perching birds. Systematic Zoology 26:19-31.

Feduccia, A., and L. D. Martin. 1976. The Eocene zygodactyl birds of North America (Aves: Piciformes). Smithsonian Contributions to Paleobiology 27:101-110.

Ferris, S. D., R. D. Sage, C. Huang, J. T. Nielsen, U. Ritte, and A. C. Wilson. 1983. Flow of mitochondrial DNA across a species boundary. Proceedings of the National Academy of Sciences, USA 80:2290-2294.

Fleischer, R. C., S. I. Rothstein, and L. S. Miller. 1991. Mitochondrial DNA variation indicates gene flow across a zone of known secondary contact between two subspecies of the brown-headed cowbird. Condor 93:185-189.

Gill, F. B., and B. Slikas. 1992. Patterns of mitochondrial DNA divergence in North American crested titmice. Condor 94:20-28.

Guyer, C., and J. M. Savage. 1986. Cladistic relationships among anoles (Sauria: Iguanidae). Systematic Zoology 35:509-531.

Hare, M. P., and G. F. Shields. 1992. Mitochondrial DNA variation in the polytypic Alaskan song sparrow. Auk 109:126-132.

Hass, C. A. 1991. Evolution and biogeography of West Indian Sphaerodactylus (Sauria: Gekkonidae): a molecular approach. Journal of Zoology, London 225:525-561.

Heatwole, H., and F. MacKenzie. 1967. Herpetogeography of Puerto Rico. IV. Paleogeography, faunal similarity and endemism. Evolution 21:429438.

Hedges, S. B. 1989. Evolution and biogeography of West Indian frogs of the genus Eleutherodactylus: Slow-evolving loci and the major groups. Pp. 305370 in C. A. Woods, ed. Biogeography of the West Indies: past, present, and future. Sandhill Crane Press, Gainesville, Fla.

Hellmayr, C. E. 1935. Birds of the Americas. Field Museum of Natural History Publications in Zoology Vol. 13, part 8, pp. 363-385. Field Museum of Natural History, Chicago.

Hixson, J. E., and W. M. Brown. 1986. A comparison 
of small ribosomal RNA genes from the mitochondrial DNA of the great apes and humans: Sequence, structure, evolution, and phylogenetic implications. Molecular Biology and Evolution 3:1-18.

Jones, J. K., Jr. 1989. Distribution and systematics of bats in the Lesser Antilles. Pp. 645-660 in C. A. Woods, ed. Biogeography of the West Indies: past, present, and future. Sandhill Crane Press, Gainesville, Fla.

Kessler, L. G., and J. C. Avise. 1985. A comparative description of mitochondrial DNA differentiation in selected avian and other vertebrate genera. Molecular Biology and Evolution 2:109-125.

Klein, N. K. 1992 . Historical processes and the evolution of geographic variation patterns in the yellow warbler (Dendroica petechia). Ph.D. diss. University of Michigan, Ann Arbor.

Kluge, A. G. 1988. Parsimony in vicariance biogeography: A quantitative method and a Greater Antillean example. Systematic Zoology 37:315-328.

Koopman, K. F. 1989. A review and analysis of the bats of the West Indies. Pp. 635-644 in C. A. Woods, ed. Biogeography of the West Indies: past, present, and future. Sandhill Crane Press, Gainesville, Fla.

Lack, D. 1973. The numbers and species of hummingbirds in the West Indies. Evolution 27:326337.

1976. Island biology. Blackwell Scientific, Oxford.

Lansman, R. A., R. O. Shade, J. F. Shapira, and J. C. Avise. 1981. The use of restriction endonucleases to measure mitochondrial DNA sequence relatedness in natural populations. III. Techniques and potential applications. Journal of Molecular Evolution 17:214-226.

MacArthur, R. H., and E. O. Wilson. 1963. An equilibrium theory of insular biogeography. Evolution 17:373-387.

- 1967. The theory of island biogeography. Princeton University Press, Princeton, N.J.

Mack, A. L., F. B. Gill, R. Colburn, and C. Spolsky. 1986. Mitochondrial DNA: a source of genetic markers for studies of similar passerine bird species. Auk 103:676-681.

Maddison, W. P., M. J. Donoghue, and D. R. Maddison. 1984. Outgroup analysis and parsimony. Systematic Zoology 33:83-103.

McDonald, M. A., and M. H. Smith. 1990. Speciation, heterochrony, and genetic variation in Hispaniolan Palm-tanagers. Auk 107:707-717.

Mengel, R. M. 1964 . The probable history of species formation in some northern wood warblers $(\mathrm{Pa}-$ rulidae). Living Bird 3:9-44.

Miller, L. D., and J. Y. Miller. 1989. The biogeography of West Indian butterflies (Lepidoptera: Papilionoidea, Hesperioidea): a vicariance model. Pp. 229-262 in C. A. Woods, ed. Biogeography of the West Indies: past, present, and future. Sandhill Crane Press, Gainesville, Fla.

Moore, W. S., J. H. Graham, and J. T. Price. 1991. Mitochondrial DNA variation in the Northern Flicker (Colaptes auratus, Aves). Molecular Biology and Evolution 8:327-344.

Moritz, C., T. E. Dowling, and W. M. Brown. 1987. Evolution of animal mitochondrial DNA: Rele- vance for population biology and systematics. Annual Review of Ecology and Systematics 18:269292.

Nei, M., and F. Tajima. 1983. Maximum likelihood estimation of the number of nucleotide substitutions from restriction site data. Genetics 105:207217.

Neigel, J. E., and J. C. Avise. 1986. Phylogenetic relationships of mitochondrial DNA under various demographic models of speciation. Pp. 515-534 in E. Nevo and S. Karlin, eds. Evolutionary processes and theory. Academic Press, New York.

Olson, S. L. 1976. Oligocene fossils bearing on the origins of the Todidae and Momotidae (Aves: Coraciiformes). Pp. 111-119 in S. L. Olson, ed. Collected papers in avian paleontology honoring the 90 th birthday of Alexander Wetmore. Smithsonian Contributions to Paleobiology 27.

1978. A paleontological perspective of West Indian birds and mammals. Pp. 99-117 in F. B. Gill, ed. Zoogeography in the Caribbean. Proceedings of the Academy of Natural Sciences, Philadelphia Special Publications 13.

. 1985. The fossil record of birds. Avian Biology 8:80-238.

Ovendon, J. R., A. Wust-Saucy, R. Bywater, N. Brothers, and R. W. G. White. 1991. Genetic evidence for philopatry in a colonially nesting seabird, the Fairy Prion (Pachyptila turtur). Auk 108:688-694.

Phillips, C. J., D. E. Pumo, H. H. Genoways, and P. E. Ray. 1989. Caribbean island zoography: A new approach using mitochondrial DNA to study Neotropical bats. Pp. 661-684 in C. A. Woods, ed. Biogeography of the West Indies: past, present, and future. Sandhill Crane Press, Gainesville, Fla.

Phillips, C. J., D. E. Pumo, H. H. Genoways, P. E. Ray, and C. A. Briskie. 1991. Mitochondrial DNA evolution and phylogeography in two Neotropical bats, Artibeus jamaicensis and Artibeus lituratus. Pp. 97-123 in M. A. Mares and D. J. Schmidly, eds. Latin American mammalogy: history, biodiversity, and conservation. University of Oklahoma Press, Norman.

Powell, J. R. 1983. Interspecific cytoplasmic gene flow in the absence of nuclear gene flow: Evidence from Drosophila. Proceedings of the National Academy of Sciences, USA 80:492-495.

Pregill, G. K. 1981. An appraisal of the vicariance hypothesis of Caribbean biogeography and its application to West Indian terrestrial vertebrates. Systematic Zoology 30:147-155.

Pregill, G. K., and S. L. Olson. 1981. Zoogeography of West Indian vertebrates in relation to Pleistocene climatic cycles. Annual Review of Ecology and Systematics 12:75-98.

Pumo, D. E., E. Z. Goldin, B. Elliot, C. J. Phillips, and H. H. Genoways. 1988. Mitochondrial DNA polymorphism in three Antillean island populations of fruit bat, Artibeus jamaicensis. Molecular Biology and Evolution 5:79-89.

Raikow, R. J. 1978. Appendicular myology and the relationships of the New World nine-primaried oscines (Aves: Passeriformes). Bulletin of the Carnegie Museum of Natural History 7:1-43.

Rauchenberger, M. 1988. Historical biogeography of 
poeciliid fishes in the Caribbean. Systematic Zoology 37:356-365.

Ricklefs, R. E., and G. W. Cox. 1972. Taxon cycle in the West Indian avifauna. American Naturalist 106:195-219.

- 1978. Stage of taxon cycle, habitat distribution, and population density in the avifauna of the West Indies. American Naturalist 112:875-895.

Ridgely, R. S. 1976. A Guide to the birds of Panama. Princeton University Press, Princeton, N.J.

Rosen, D. E. 1975. A vicariance model of Caribbean biogeography. Systematic Zoology 24:431-464.

Seutin, G., J. Brawn, R. E. Ricklefs, and E. Bermingham. 1993. Genetic divergence among populations of a tropical passerine, the streaked saltator ( $\mathrm{Sal}$ tator albicollis). Auk 110:117-126.

Shields, G. F., and K. M. Helm-Bychowski. 1988. Mitochondrial DNA of birds. Current Ornithology 5:273-295.

Shields, G. F., and A. C. Wilson. 1987. Subspecies of the Canada Goose (Branta canadensis) have distinct mitochondrial DNA's. Evolution 41:662-666.

Sibley, C. G., and J. E. Ahlquist. 1990. Phylogeny and classification of birds: a study in molecular evolution. Yale University Press, New Haven, Conn.

Smith, G. R. 1992. Introgression in fishes: significance for paleontology, cladistics, and evolutionary rates. Systematic Biology 41:41-59.

Swofford, D. L. 1991. PAUP: Phylogenetic analysis using parsimony, Version 3.0. Computer program distributed by the Illinois Natural History Survey, Champaign, Ill.

Swofford, D. L., and G. J. Olsen. 1990. Phylogeny reconstruction. Pp. 41-50 in D. M. Hillis and C. Moritz, eds. Molecular systematics. Sinauer, Sunderland, Mass.

Tajima, F. 1983. Evolutionary relationship of DNA sequences in finite populations. Genetics 105:437460.

Takahata, N. 1989. Gene genealogy in three related populations: consistency probability between gene and population trees. Genetics 122:957-966.

Takahata, N., and M. Slatkin. 1984. Mitochondrial gene flow. Proceedings of the National Academy of Sciences, USA 81:1764-1767.

Tegelstrom, H. 1987. Transfer of mitochondrial DNA from the northern Red-backed Vole (Clethrionomys rutilus) to the Bank Vole ( $C$. glareolus). Journal of Molecular Evolution 24:218-227.

Templeton, A. R. 1983a. Convergent evolution and nonparametric inferences from restriction data and DNA sequences. Pp. 151-179 in B. S. Weir, ed. Statistical analysis of DNA sequence data. Marcel Dekker, New York.

- 1983b. Phylogenetic inference from restric- tion endonuclease cleavage site maps with particular reference to the evolution of humans and the apes. Evolution 37:221-244.

. 1987. Genetic systems and evolutionary rates. Pp. 218-234 in K. F. S Campbell and M. F. Day eds. Rates of evolution. Australian Academy of Sciences, Canberra.

Terborgh, J. W., J. Faaborg, and H. J. Brockmann. 1978. Island colonization by Lesser Antillean birds. Auk 95:59-72.

Van Wagner, C. E., and A. J. Baker. 1990. Association between mitochondrial DNA and morphological evolution in Canada Geese. Journal of Molecular Evolution 31:373-382.

Vawter, L., and W. M. Brown. 1986. Nuclear and mitochondrial DNA comparisons reveal extreme rate variation in the molecular clock. Science 234 : 194-196.

Wiedenfeld, D. A. 1991. Geographical morphology of male yellow warblers. Condor 93:712-723.

Wiley, E. O. 1981. Phylogenetics: the theory and practice of phylogenetic systematics. Wiley, New York.

Williams, E. E. 1989. Old problems and new opportunities in West Indian biogeography. Pp. 1-46 in C. A. Woods, ed. Biogeography of the West Indies: past, present, and future. Sandhill Crane Press, Gainesville, Fla.

Wilson, A. C., R. L. Cann, S. M. Carr, M. George, U. Gyllensten, K. Helm-Bychowski, R. G. Higuchi, S. R. Palumbi, E. M. Prager, R. Sage, and M. Stoneking. 1985. Mitochondrial DNA and two perspectives on evolutionary genetics. Biological Journal of the Linnean Society 26:375-400.

Woods, C. A. 1989. The biogeography of West Indian rodents. Pp. 741-798 in C. A. Woods, ed. Biogeography of the West Indies: past, present, and future. Sandhill Crane Press, Gainesville, Fla.

Wright, J. M., C. Spolsky, and W. M. Brown. 1983. The origin of the parthenogenetic lizard Cnemidophorus laredoensis inferred from mitochondrial DNA analysis. Herpetologica 39:410-416.

Wu, C.-I. 199I. Inferences of species phylogeny in relation to segregation of ancient polymorphisms. Genetics 127:429-435.

Zink, R. M. 1991. The geography of mitochondrial DNA variation in two sympatric sparrows. Evolution 45:329-339.

Zink, R. M., W. L. Rootes, and D. L. Dittman. 1991. Mitochondrial DNA variation, population structure, and evolution of the common grackle (Quiscalus quiscula). Condor 93:318-329.

Corresponding Editor: A. Larson 